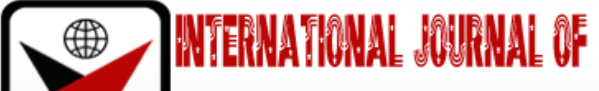 \\ X
}

ISSN 2278-0211 (Online)

\section{Strategies Used by Secondary School Teachers in the Implementation of Practical Skills for the Realization of Vision 2025 among Ordinary Level Secondary School Learners in Kilimanjaro Region, Tanzania}

\author{
Kezia J. Mashingia \\ Ph.D. Candidate Department of Education, Mwenge Catholic University, Tanzania \\ Malusu, JM. \\ Associate Professor, Department of Education, Mwenge Catholic University, Tanzania \\ Dr. P Kireti \\ Lecturer, Department of Education, Mwenge Catholic University, Tanzania
}

\begin{abstract}
:
Vision 2025 recommends that education should lead to high quality livelihood for all Tanzanians through strategies which ensure attainment of a level of tertiary education, hard work and creativity through implementation of practical skills among learners. Strategies used by secondary school teachers in the Implementation of Practical Skills for the realization of Vision 2025 among secondary school learners have not been documented in Kilimanjaro Region. Thus, the aim of undertaking this study was to document this study and to find out common strategies used by secondary school teachers whether these strategies helped learners acquire practical skills for the realization of Vision 2025 or not. This paper addresses one of the research questions: Which strategies are used by secondary school teachers in implementing practical skills for the realization of Vision 2025 in Kilimanjaro Region, Tanzania? This study used convergent mixed methods design which is a concurrent design where qualitative data and quantitative data sets are collected together. The target population was 5278 people including DEOs, secondary school teachers, heads of schools, academic masters and Form four learners of government and private secondary schools of three district councils. Probability and non-probability sampling were used. Data were collected through questionnaires, interview guide, document analysis schedule and observation schedule. Findings indicated that commonly used strategies were developing practical projects for learners, assigning learners practical tasks such as farming, and demonstration of practical activities. The practical skill activities or tasks included farming, carpentry, cookery and generic practical skills developed included problem solving, critical thinking, creative thinking and digital literacy. Practical skills acquired could help learners in employment opportunities. In conclusion this implied that Vision 2025 could be realized through secondary education by learners acquiring practical skills which help them improve their livelihood. The researcher recommended practical skills to be developed to A level, Tertiary and University level; practical skill subjects focused in this study such as, agriculture and building to be made compulsory in all secondary schools. For future research, a study may investigate significant factors which influence the effectiveness of practical skill activities among learners in Kilimanjaro Region, Tanzania.
\end{abstract}

Keywords: Implementation, practical skills, strategies, vision

\section{Introduction}

The Vision 2025 which was launched in 2000 has three pillars namely, high quality livelihood for all Tanzanians; good governance and rule of law; a strong and competitive economy (Planning Commission,2000). Vision 2025 recommends that education should lead to high quality livelihood for all Tanzanians; developmental mind set and empowering culture; development of oriented culture, hard work and creativity; education as a strategic change agent; promotion of science and technology education; promotion of information and communication technologies (Planning Commission, 2000). In this study the focus was on one of the Vision 2025 objectives which is high quality livelihood for all Tanzanians expected to be attained through strategies which ensure the attainment of a level of tertiary education, hard work, and creativity through implementation of practical skills among learners for the realization of Vision 2025.These were to be achieved through education by focusing on specific subjects. Vision 2025 targeted subjects such as agriculture, business, ICT, together with STEM subjects namely science, technology, engineering and mathematics. The Ministry of Education, Science and Technology (MoEST) has identified these subjects and teachers are being trained in these subjects in ear marked science colleges and universities. These subjects are also stipulated in the reviewed curriculum (TIE, 2013). 
These subjects are taught in some schools as optional and in some schools as core subjects. The study focused on the following subjects: agriculture- farming; home economics; Building construction- brickwork, electrical installation; Book keeping and Commerce; Computer Information Technology; Fine art and Music (Table 1). These subjects have related or similar skills to STEM. The question is that are secondary school teachers teaching these subjects using strategies suggested by the curriculum? This question was addressed in the findings of the current study.

Implementation of practical skills among secondary school learners has been a great concern to educationists. For example, Nyerere's idea of Education for Self Reliance (1967) emphasized integrating theory and practical skill activities. Outside the classroom learners learned practical skills from practical skill activities such as farming, livestock keeping, making bricks and carpentry. The secondary school curriculum revised by TIE (2013) emphasizes strategies such as demonstration of practical activities, developing projects for learners, organizing debates which enable learners to acquire practical skills(generic) such as problem solving, critical thinking and digital literacy. The question is that, what practical skills are taught by secondary school teachers which help the realization of Vision 2025 in Kilimanjaro region? These concerns prompted the researcher to investigate strategies used by secondary school teachers in the implementation of practical skills for the realization of Vision 2025 in Kilimanjaro region, Tanzania. These concerns have been addressed in the findings of this study.

\subsection{Statement of the Problem}

Since Vision 2025 was launched in 2000, many curriculum innovations have been put in place. Practical subjects have been introduced and made compulsory to ensure learners left secondary schools with practical skills. What is not known is whether the teachers have been trained on teaching these practical skills to learners and if they have been dully trained, it is important to find out if they are actually teaching as recommended Yet, stakeholders, Education officers, teachers, learners and parents are still concerned with ordinary secondary education in leading to the realization of Vision 2025. Few research studies have been done on strategies delivering practical skills among learners. These include: Chib and Wardoyo (2018) Singapore; Odo et al. (2017) Nigeria; Hamamba and Rao (2017) and Mtebe et al. (2018) Tanzania. These studies have examined practical skills' training in general in different countries. Few studies have dealt with these practical skills in particular reference to Vision 2025.No known particular study has dealt with strategies used by secondary school teachers in implementing practical skills for the realization of Vision 2025 among secondary school learners. Also, up to now, we do not have proper documentation to see whether we are moving towards the attainment of Vision 2025 through secondary education. Therefore, the purpose of this study was to document the findings and to find out strategies used by secondary school teachers in the implementation of practical skills for the realization of Vision 2025 in Kilimanjaro Region, Tanzania.

\subsection{Research Question}

The study was guided by one research question:

- 1 . What strategies are used by secondary school teachers in the implementation of practical skills for the realization of Vision 2025 in Kilimanjaro region?

\subsection{Hypothesis}

There is a significant relationship between rate mean scores of strategies used by secondary school teachers and implementation of practical skills for the realization of Vision 2025 among secondary school learners.

\subsection{Theoretical Framework}

This study was guided by This study was guided by the Theory of Overcoming Resistance to Change (ORC) by Coch and French (1948) who suggested that change can be directed, managed and controlled. The model assumes that success or failure of curriculum implementation is dependent on how the curriculum developer influences the curriculum, the teachers, the students and the public because they are the ones who may resist change at the time of introduction of a new programme. In effect the model advocates for identification and effectively dealing with the concerns of the teachers during implementation process (Coch\& French, 1948).

If we desire change then we must address people's misgivings, their misapprehensions, or other such related factors. To get the desired result curriculum developers should identify and deal with the concerns of the staff in various educational institutions when implementing new curriculum (Coch\&French, 1948). At normal circumstances, people want to change but at the same time have certain concerns. This creates some resistance at the outset. Success or failure of implementation of practical skills then would depend on whether or not a teacher overcomes the resistance (Ahmed, 2014). The concerns are classified into four categories. They are insignificant concerns; personal concerns; task-related concerns; and impact-related concerns.

- Unrelated/insignificant concerns-Teachers do not perceive the suggested changes as related to them and so do not feel that they should concern themselves with the efforts to change.

- Personal concerns-Teachers react to innovations in relation to their situation. How well each one feels he /she could deal with the new changes

- Task- related Concerns-Teacher is concerned about the actual use of innovation in the classroom- issues of materials and strategies for implementation.

- Impact related concerns-Teacher is concerned about the effect of the innovation on the learners, colleagues and community. 
Curriculum planners can deal with these concerns better if they involve those in the implementation right away i.e., at the planning stage. They can then discuss how these concerns can be addressed (Ahmed, 2014).

\section{Literature Review}

Referring to Chib and Wardoyo (2018) study on 'Differential OER Impacts of Formal and Informal ICTs: Employability of Female Migrant Workers' in Singapore, a survey was conducted amongst female domestic workers $(\mathrm{n}=100)$ enrolled in the Indonesia Open University in Singapore. The results of the study were that access to OER via computers in the formal context of institutional learning, when combined with employability awareness, had a significant influence on the livelihood outcomes that is perceived employability (Chib\&Wardoyo, 2018). But this did not lead to actual improvement in learning- functional literacy; instead, actual learning improvement was influenced by digital skills enabled by mobile phones and computers (Chib\&Wardoyo, 2018). The researchers concluded with a discussion on policy implications for digital skills training via mobile devices for marginalized population to bolster the positive effects of OER on livelihood outcomes. The researchers too commended that Information and Communication Technologies aid employment opportunities (Chib\& Wardoyo,2018).

Thus, if Information Technology could then be used well in secondary schools for the development of practical skills for the realization of Vision 2025; it is obvious that learners would acquire practical skills suitable for paid work or employ themselves. However, the researchers did not streamline the policy implications to be adhered to if digital training was to be affected. Also, mobile phones and computers are expensive and in the case of Tanzania even power cuts can affect the training of learners on digital training. Thus, the current study assessed digital literacy as one of the practical skills developed among secondary school learners for the implementation of Vision 2025.

Researchers, Amaechi and Joseph, (2016) conducted a study on 'Strategies of effective teaching and learning practical skills in Technical and Vocational Training Programmes in Nigeria' Their study examined teaching strategies that are applicable in delivering practical skills in technical and vocational education in Nigeria. Relevant strategies found in the study were demonstration methods, assignment methods, developing projects and computer simulations. However, this study investigated strategies applicable in delivering practical skills among learners in secondary schools and not technical nor vocational schools though the strategies themselves might be the same. The researchers too did not make a clear distinction between strategies and acquired practical skills, they used them interchangeably.

Also, Odo et al. (2017) conducted a study in Nigeria on Technical Education-The key to Sustainable Technological Developments. Technical education has been identified as one of the most effective human resource developments that needs to be embraced for rapid industrialization and sustainable technological development of any nation (Odo et al .2017). Technical education has been an integral part of national development in many societies because of its impact on productivity and economic development, Odo et al. (2017) because learners are involved in doing practical skills. Also, technical education is education that prepares learners for specific trades, crafts, technical or professional position in engineering, accountancy, nursing, medicine, architecture, pharmacy, law and many others (Odo et al .2017). But the researchers did not focus on strategies which teachers should use in order to enhance technical education and to prepare learners for specific trades. But the current study investigated the common strategies used by secondary school teachers in implementation of practical skills among learners for the realization of Vision 2025.

Additionally, Rafai et al. (2014), did a study basing on Assessment of Teaching Methods that Influence the Acquisition of Practical Skills in Nigeria. The study identified different practical teaching methods which teachers could use in enhancing practical skills. These methods included organizing fieldtrips, organizing discussions, making demonstrations and simulations. The researchers recommended that teachers and administrators in the schools should be encouraged to use different instructional methods which were most significant determinants of teaching methods that influenced the acquisition of practical skills. This will enable learners acquire the practical skills for gainful employment in the labour market or be able to establish on their own and become self-reliant. But the researchers did not identify significant strategies which commonly influenced the acquisition of practical skills in Nigeria. The present study investigated commonly used strategies used by secondary school teachers in the implementation of practical skills among learners for the realization of Vision 2025.

Referring to Hamamba and Rao (2017) study on 'Preparation and Professional Development of Teacher Educators in Tanzania: Current Practices and Prospects' and basing on the findings, teachers should be provided with practical skills that would help them teach the learners more effectively and acquire practical skills too. The researchers did not identify the type of practical skills to be taught to teachers in order to teach well practical skills among learners. In the current study the researcher identified the common practical skill activities such as farming, needlework which secondary school teachers were using in teaching practical skills among learners because some learners finished secondary education without mastering practical skills for employment opportunities, why? Was it that teachers were not taught practical skills and therefore could not teach practical skills among learners or there was another reason? These concerns were addressed in the findings of this study.

Referring to Mtebe et al. (2018) study on Eliciting in-service Teacher's Technological Pedagogical Content Knowledge for $21^{\text {st }}$ Century Skills in Tanzania, the findings provided valuable insights on how teachers used ICT to prepare learners for $21^{\text {st }}$ Century skills capable of supporting the country's efforts towards an industrial economy. The researchers did not identify what other $21^{\text {st }}$ Century skills were and what strategies teachers could use to affect the $21^{\text {st }}$ century practical skills for the realization of Vision 2025. The current study however, identified a number of common practical skills delivered by secondary school teachers among learners for the realization of Vision 2025.

Referring to Lupeja (2017) study on, 'Secondary Education Attainment and its Role in Poverty Reduction: Views of Graduates Working in Informal Sector in Rural Tanzania', secondary education graduates preferred nonfarm activities 
and informal activities than farm activities (Lupeja, 2017). The study revealed that teaching, learning, and the curriculum content itself were not sufficient to prepare competent candidates in the informal sector. What had been taught were the basic skills which could not prepare a candidate to be competent enough in the informal sector (Lupeja, 2017). The researcher did not specify the basic skills taught among secondary school learners which he said did not prepare candidates to be competent enough in the in formal sector. Also, the researcher did not suggest what skills should then be taught secondary school learners in order to employ themselves in the informal sector. Though the curriculum claimed to prepare learners to be productive, entrepreneurial and could address challenges emanating from the prevailing socioeconomic situation TIE (2010), what had been done in the classroom did not reflect the policy statements (Lupeja,2017). Therefore, this study investigated the strategies used by teachers in delivering practical skills among secondary school learners in the implementation of practical skills for the realization of Vision 2025

\subsection{Research Gap}

Few research studies were reviewed from different parts of the world on strategies used by secondary school teachers in the implementation of practical skills among learners such as Chib and Wardonyo (2018), Singapore; Odo et al. (2017), Nigeria; Rafai et.al. (2014), Nigeria; Hamamba and Rao (2017), Tanzania. These studies examined strategies used by secondary school teachers in the implementation of practical skills in general and not with particular reference to Vision 2025. No known research study has dealt with strategies used by secondary school teachers in the implementation of practical skills among secondary school learners in Kilimanjaro Region, Tanzania. Also there is no proper documentation to see whether we are moving towards the attainment of Vision 2025 through secondary education. Therefore the purpose of the study was to document the findings of this study and to investigated strategies used by secondary school teachers in the implementation of practical skills among secondary school learners for the realization of Vision 2025, in Kilimanjaro Rregion, Tanzania.

\subsection{Research Design and Methodology}

This study used Convergent Mixed Methods Design (Creswe\&Creswell,2018) which is a concurrent design where Qualitative and Quantitative data sets are collected together in a single phase and then analyzed. The findings are merged and interpreted to compare quantitative and qualitative data to see whether they conform or not. Mixed research methods provide richer insights into phenomena of interest that cannot be fully understood using only quantitative or qualitative methods (Johnsonet al.2007). The researcher used this design in order to build on the strengths of both quantitative and qualitative data and produce enough information for extending and elaborating the problem of the study (Creswell \& Clark, 2018).

Quantitative data were collected through questionnaires and document analysis schedule and then were coded, entered into the computer and analyzed using SPSS version 23 into descriptive and inferential statistics. Descriptive data such as mean, mode and median were analyzed into frequencies and percentages and then presented into tables and graphs. Inferential statistics such as Regression were analyzed into Mean and SD and then used to test the hypothesis. The qualitative information was coded into themes, descriptively analyzed and major summaries were reported together with some direct quotations and narrations. Then the researcher combined the two data by form of integration.

The target population was 5278 people including DEOs, secondary school teachers, heads of schools, academic masters, and Form four learners of all government and private ordinary level secondary schools in the 3 District councils in Kilimanjaro region. Then the researcher sampled 11government and private ordinary level secondary schools from the 3 sampled District Councils so as to obtain a representative sample for the whole population. A representative sample of 3 DEOs, 11 heads of schools, 11 academic masters, 110 secondary school teachers, and 396 Form four learners totaling to 531 participants were used in collecting data.

\section{Results and Discussion}

The presentation and discussion of findings started with findings organized according to the sub divisions of the research question.

\subsection{Focused Practical Subjects Offered in the School Curriculum in the Sampled Schools}

The researcher carried out document analysis schedule of the subjects the schools offer in the sampled 11 secondary schools and looked at the time tables to determine the number of practical subjects being taught in those secondary schools. Table 1 gives a summary of what the researcher found. 


\begin{tabular}{|c|c|c|c|c|}
\hline Subject Name & \multicolumn{2}{|c|}{ Offered in Schools } & \multicolumn{2}{c|}{ Not Offered in Schools } \\
\hline & Frequency & Percent & Frequency & Percent \\
\hline Agriculture-farming & 8 & 72.7 & 3 & 27.3 \\
\hline Home economics & 4 & & & 72.7 \\
\hline $\begin{array}{c}\text { Computer information Technology } \\
\begin{array}{c}\text { Building construction (brick work, } \\
\text { electrical installation) }\end{array}\end{array}$ & 3 & 27.2 & 10 & 90.0 \\
\hline Fine arts & 3 & 9.0 & 8 & 72.7 \\
\hline Music & 3 & 27.2 & 8 & 72.7 \\
\hline Book keeping\& Commerce & 3 & 27.2 & 8 & 72.7 \\
\hline Sports and games & 11 & 100 & - & - \\
\hline
\end{tabular}

Table 1: Focused Practical Subjects in Sampled Schools $(N=11)$

Source: Field Data, (2020)

Table 1 shows the subjects which were focused in the study. These subjects are stipulated in the secondary school curriculum reviewed by TIE (2013). Some of these subjects are offered in secondary schools as core and others as optional subjects. The findings show that many schools practiced farming and sports and games. Agriculture is taught in 8 of the 11 secondary schools visited and sports and games were offered in all 11 secondary schools visited. The other subjects are taught in very few secondary schools visited. For example, only one school offered building construction; 4 secondary schools offered home economics; computer information technology, Fine art, Music, Book keeping and commerce each was offered in 3 secondary schools.

\subsection{Strategies Used by Secondary School Teachers in the Implementation of Practical Skills for the Realization of Vision 2025} among Ordinary Level Secondary School Learners in Kilimanjaro Region

This study focused on the direct practical oriented subjects other than science subjects namely agriculturefarming, business studies- book keeping and commerce, computer studies, home economics, technical subjects- building, brick work, electrical installation, fine art and music (Table 1). The syllabus emphasizes strategies such as demonstrating practical tasks and assigning tasks to learners such as farming, computer work and needle work. These subjects too enhance practical skills such as problem solving, creative thinking and digital literacy all of which are stipulated in the syllabus. These subjects have similar skills to STEM which is an approach to learning and development that integrates the areas of science, technology engineering and mathematics (www.education.wa.edu.au/what is STEM). Through STEM learners develop key practical skills including problem solving, critical thinking, digital literacy, and initiative. STEM education creates critical thinkers, increases science literacy and enables the next generation of innovators. The STEM skills are similar to the practical skills emphasized in the secondary school curriculum TIE (2013) and so the study did not focus on STEM, but focused on similar or related skills to STEM.

Strategies in this study mean teaching methods or techniques such as demonstrating practical tasks to learners, assigning learners practical tasks such as farming, integration of ICT with teaching and other practical skill activities which are used to develop practical skills among learners outside the classroom such as building, carpentry, and livestock keeping. Thus, the researcher sought to find out the common strategies which teachers used in implementing practical skills for the realization of Vision 2025.The information was collected from teachers because teachers are the implementers of secondary school curriculum. The researcher was interested to know the strategies used in implementing practical skills and the responses are summarized in table 2

\begin{tabular}{|c|c|c|c|c|}
\hline & \multicolumn{2}{|c|}{ Yes } & \multicolumn{2}{c|}{ No } \\
\hline Strategies & f & $\mathbf{\%}$ & f & \% \\
\hline Assigning learners practical tasks such as farming & 71 & 64.5 & 39 & 35.5 \\
\hline Developing practical projects for learners e.g., piggery unit & 74 & 67.3 & 36 & 32.7 \\
\hline Demonstrating practical activities e.g., carpentry & 101 & 91.8 & 9 & 8.2 \\
\hline $\begin{array}{c}\text { Observing and assessing learners when they perform tasks e.g., sewing, brick } \\
\text { making etc }\end{array}$ & 96 & 87.3 & 14 & 12.7 \\
\hline Integrating ICT with teaching and learning & 80 & 72.7 & 30 & 27.3 \\
\hline Assessing ability of learners in the practical activity they do & 56 & 50.9 & 54 & 49.1 \\
\hline Organizing field trips and escorting learners & 75 & 68.2 & 35 & 31.8 \\
\hline sand, cement and water for brick making & 93 & 84.5 & 17 & 15.5 \\
\hline Assessing the overall quality of (performance, durability) the completed task & 79 & 71.8 & 31 & 28.2 \\
\hline Assessing learners' promptness in starting the practical activities given & 67 & 60.9 & 43 & 39.1 \\
\hline Determining the objectives to be achieved at the end of the practical session & 84 & 76.4 & 26 & 23.6 \\
\hline Preparing observational check list for a fair and consistent appraisal of the & 74 & 67.3 & 36 & 32.7 \\
\hline learners & & & & \\
\hline Assessing learners' independent handling of practical tasks & 62 & 56.4 & 48 & 43.6 \\
\hline
\end{tabular}

Table 2: Responses of Teachers on the Strategies They Used to Develop Practical Skills (N=110)

Source: Field Data, (2020) 
Table 2: shows that many teachers (56.4\% -91.8\%) said 'yes' to all the strategies such as demonstrating practical activities, observing learners doing practical tasks and assigning learners practical tasks such as farming. This was so because these strategies are basic in teaching and they enhance effective teaching and learning process. For example, the teacher has to demonstrate the practical activities such as needlework - sewing a dress before learners start sewing so that learners can perform better. These strategies helped the acquisition of practical skills among secondary school learners and they allow the learner to be actively involved in the learning process. This is supported by the theory of social constructivism (Vygotsky,1998) which allows learners to construct knowledge and become active in the mental and motor activities.

Similarly, other strategies with smaller proportions of respondents such as assessing learners independent handling of practical skills and assessing ability of learners in the practical activity were strategies which helped the implementation of practical skills for the realization of Vision 2025 among secondary school learners. These strategies are in line with TIE (2013), ESDP (1997) and Muneja (2015) who emphasized that these strategies are important in enhancing practical skills for realization of Vision 2025 among secondary school learners. Based on the findings, the identified strategies from teachers are consistent with those identified by the heads of schools indicating cooperation among themselves (triangulation). The researcher too was interested in knowing the frequency use of strategies used by secondary school teachers.

\subsection{Frequency Use of Strategies Used by Ordinary Level Secondary School Teachers}

The researcher also sought information on the rate of frequency use of strategies teachers used for the implementation of practical skills among learners. The teachers rated the frequency use of the strategies they used and the responses are summarized in table 3

\begin{tabular}{|c|c|c|c|c|c|c|c|c|c|c|c|c|}
\hline \multirow[b]{2}{*}{ Strategies } & \multicolumn{2}{|c|}{$\begin{array}{l}\text { Not } \\
\text { Used }\end{array}$} & \multicolumn{2}{|c|}{ Very Rarely } & \multicolumn{2}{|c|}{ Rarely } & \multicolumn{2}{|c|}{ Often } & \multicolumn{2}{|c|}{ Very Often } & \multicolumn{2}{|c|}{$\begin{array}{c}\text { Descriptive } \\
\text { Statistics }\end{array}$} \\
\hline & $\mathbf{f}$ & $\%$ & $\mathbf{f}$ & $\%$ & $\mathbf{f}$ & $\%$ & $\mathbf{f}$ & $\%$ & $\mathbf{f}$ & $\%$ & Mean & $\begin{array}{l}\text { Standard } \\
\text { deviation }\end{array}$ \\
\hline $\begin{array}{l}\text { Assigning learners practical } \\
\text { tasks such as farming }\end{array}$ & 4 & 3.8 & 9 & 8.7 & 9 & 8.7 & 25 & 24.0 & 57 & 54.8 & 4.17 & 0.930 \\
\hline $\begin{array}{l}\text { Developing practical projects } \\
\text { for learners }\end{array}$ & 0 & 0.0 & 5 & 5.2 & 22 & 22.7 & 28 & 28.9 & 42 & 43.3 & 4.10 & 0.682 \\
\hline $\begin{array}{l}\text { Demonstrating practical } \\
\text { activities e.g., carpentry }\end{array}$ & 0 & 0.0 & 0 & 0.0 & 11 & 10.8 & 22 & 21.6 & 69 & 67.6 & 4.57 & 0.675 \\
\hline $\begin{array}{l}\text { Observing and assessing } \\
\text { learners when they perform } \\
\text { tasks e.g., brick making }\end{array}$ & 0 & 0.0 & 2 & 2.0 & 4 & 4.0 & 32 & 32.3 & 61 & 61.6 & 4.54 & 0.997 \\
\hline $\begin{array}{l}\text { Integrating ICT with teaching } \\
\text { and learning process }\end{array}$ & 3 & 3.0 & 3 & 3.0 & 13 & 12.9 & 28 & 27.7 & 54 & 53.5 & 4.26 & 0.904 \\
\hline $\begin{array}{l}\text { Assessing ability of learners in } \\
\text { the practical activities they do }\end{array}$ & 2 & 2.0 & 5 & 4.9 & 18 & 17.6 & 50 & 49.0 & 27 & 26.5 & 3.93 & 0.806 \\
\hline $\begin{array}{l}\text { Organizing field trips and } \\
\text { escorting learners }\end{array}$ & 2 & 1.9 & 2 & 1.9 & 31 & 29.8 & 53 & 51.0 & 16 & 15.4 & 3.76 & 0.819 \\
\hline $\begin{array}{l}\text { Identifying appropriate tools } \\
\text { and materials for the practical } \\
\text { tasks e.g., and, water, cement } \\
\text { for brick making }\end{array}$ & 1 & 1.1 & 1 & 1.1 & 11 & 11.6 & 27 & 28.4 & 55 & 57.9 & 4.41 & 0.841 \\
\hline $\begin{array}{c}\text { Assessing the overall quality } \\
\text { of (performance, durability) } \\
\text { the completed task }\end{array}$ & 0 & 0.0 & 4 & 3.9 & 11 & 10.8 & 18 & 17.6 & 69 & 67.6 & 4.49 & 0.820 \\
\hline $\begin{array}{c}\text { Assessing learners' } \\
\text { promptness in starting the } \\
\text { practical activities given }\end{array}$ & 0 & 0.0 & 6 & 5.7 & 8 & 7.5 & 48 & 45.3 & 44 & 41.5 & 4.23 & 1.037 \\
\hline $\begin{array}{c}\text { Determining the objectives to } \\
\text { be achieved at the end of the } \\
\text { practical session }\end{array}$ & 4 & 4.1 & 4 & 4.1 & 27 & 27.8 & 34 & 35.1 & 28 & 28.9 & 3.80 & 0.925 \\
\hline $\begin{array}{l}\text { Preparing observational check } \\
\text { list for a fair consistent } \\
\text { appraisal of learners }\end{array}$ & 1 & 1.0 & 8 & 7.6 & 14 & 13.3 & 48 & 45.7 & 34 & 32.4 & 4.01 & 0.932 \\
\hline $\begin{array}{c}\text { Assessing learners' } \\
\text { independent handling of } \\
\text { practical tasks }\end{array}$ & 2 & 2.0 & 4 & 4.0 & 7 & 7.1 & 28 & 28.3 & 58 & 58.6 & 4.37 & 1.053 \\
\hline
\end{tabular}

Table 3: Responses of Teachers on Frequency Use of Strategies They Used to Develop Practical Skills (N=110) Source: Field Data, (2020)

Table 3: shows that the frequency use of strategies by teachers is above average $(\mathrm{M}=3.76, \mathrm{SD}=0.8 .19)$, and that teacher said they used often and very often organizing field trips and escorting learners which helps learners get new 
knowledge and skills by exploring new environments. Also, teachers said they used often and very often the teacher assigning learners practical tasks $(M=4.17, S D=0.930)$, demonstrating practical activities, observing and assessing learners performing tasks. This means that teachers are active in helping learners perform the practical tasks such as farming and this motivates learners to perform the practical tasks effectively for the realization of Vision 2025.

Slightly over ninety percent $(M=4.54, S D=0.997)$ of teachers said that they used often and very often observing and assessing learners when they performed the practical tasks and this produced better performance. Other teachers said that demonstrating practical activities were often and very often strategies used because these strategies are basic in teaching practical skills. The results too support that teacher were very often assessing the overall quality of the completed tasks in implementing practical skills for the realization of Vision 2025 among ordinary level secondary school learners in Kilimanjaro Region. These findings implied that ordinary level secondary school learners were getting knowledge and quality practical skills' abilities for the realization of Vision 2025. Teachers used these strategies very often since all the responses had mean scores above average ( $M=3.76$ - 4.57). These strategies are supported by TIE (2013), who emphasized in the curriculum that these strategies are important in enhancing practical skills for the realization of Vision 2025.

In addition, the study revealed that over 86.9 percent of teachers said that assessing learners independent handling of practical tasks was often and very often strategy used in implementing practical skills for the realization of Vision 2025. This means that the learners can be trusted in doing work assigned to them even after completing school, they could continue practicing the practical skill activities for their betterment. In addition, greater number of teachers frequently integrated ICT with teaching and learning, this is in line with the National ICT Policy (2003) and they also organized field trips. These results correspond with the findings of Rafaiet al. (2014) who identified teaching strategies enhancing practical skills in Nigeria such as organizing field trips, and demonstrations. These findings imply that if many strategies of this kind were often used, then learners would acquire practical skills for the realization of Vision 2025 . These strategies help learners to construct ideas and become actively involved in these activities, these findings concur with Vygotsky (1998) and (TIE, 2013). Table 3 shows that almost all teachers often used all the stipulated strategies often since the mean scores of the responses were all above $(M=3.76-M=4.57)$ and that where the SD was high (1.037-1.053) responses were close to each other thus learners acquired a lot of practical skills. In the same vein the researcher was interested in asking heads of schools about the strategies used by their respective teachers.

\subsection{Responses of Heads of Schools on Strategies Used by Their Respective Secondary School Teachers}

The researcher was also interested in seeking information from heads of schools about strategies used by secondary school teachers in their respective secondary schools so that the researcher could see if the responses corresponded or not (triangulation). The responses are summarized in table 4.

\begin{tabular}{|c|c|c|c|c|}
\hline Strategies & Yes & $\%$ & No & $\%$ \\
\hline Assigning learners practical tasks such as farming & 5 & 45.5 & 6 & 54.5 \\
\hline Developing practical projects for learners & 6 & 54.5 & 5 & 45.5 \\
\hline Demonstrating practical activities e.g., carpentry & 10 & 90.9 & 1 & 9.1 \\
\hline $\begin{array}{l}\text { Observing and assessing learners when they perform tasks e.g., } \\
\text { sewing, brick making etc }\end{array}$ & 11 & 100.0 & 0 & 0.0 \\
\hline Integrating ICT with teaching and learning & 11 & 100.0 & 0 & 0.0 \\
\hline Assessing ability of learners in the practical activity they do & 4 & 36.4 & 7 & 63.6 \\
\hline Organizing field trips and escorting learners & 7 & 63.6 & 4 & 36.4 \\
\hline $\begin{array}{l}\text { Identifying appropriate tools and materials needed for the } \\
\text { practical task e.g., sand, cement and water for brick making }\end{array}$ & 11 & 100.0 & 0 & 0.0 \\
\hline $\begin{array}{l}\text { Assessing the overall quality of (performance, durability) the } \\
\text { completed task }\end{array}$ & 9 & 81.8 & 2 & 18.2 \\
\hline $\begin{array}{c}\text { Assessing learners' promptness in starting the practical } \\
\text { activities given }\end{array}$ & 8 & 72.7 & 3 & 27.3 \\
\hline $\begin{array}{l}\text { Determining the objectives to be achieved at the end of the } \\
\text { practical session }\end{array}$ & 3 & 27.3 & 8 & 72.7 \\
\hline $\begin{array}{c}\text { Preparing observational check list for a fair and consistent } \\
\text { appraisal of the learners }\end{array}$ & 8 & 72.7 & 3 & 27.3 \\
\hline Assessing learners' independent handling of practical tasks & 8 & 72.7 & 3 & 27.3 \\
\hline
\end{tabular}

Table 4: Responses of Heads of Schools on Strategies Usedin Developing Practical Skills (N=11) Source: Field Data, (2020)

Table 4 shows that all (100\%) heads of schools said that teachers used the strategies of observing and assessing learners when they perform tasks, integrating ICT with teaching and learning, and identifying appropriate tools and materials for the practical task's learners were assigned. In addition, it shows that 90.9 percent of heads of schools said demonstrating practical activities and assessing the overall quality of the completed tasks were strategies used by their teachers in implementing practical skills among learners and this increased learners' practical skill abilities .This is in line with Hernandez et al. (2018) who commented that strategies in which learners are actively engaged in their learning process are the best ways to develop high level skills as well as specific career competences. 
Additionally, few heads of schools pointed out that assessing ability of learners in the practical activity (36.4\%) and determining the objectives to be achieved at the end of the task $(27.3 \%)$ were little implemented. This is not concurring with teachers' responses which were above 64.0 percent, table 3 . This implies that some heads of schools stayed in their offices and did not supervise their teachers or there was no proper communication between them to see what strategies teachers were using in teaching learners' practical skills. Also, responses of heads of schools on assessing the overall quality of the completed tasks performed by learners were consistent with teachers' responses table 3. However, despite the revealed difference in strategies between teachers and heads of schools, still learners acquired practical skills which helped learners to construct ideas and become actively involved in these activities. This concurs with Vygotsky, (1998) who propagates that learner should construct knowledge which enables them to acquire practical skills because learners become active in the mental and motor activities. When heads of schools were asked to comment on whether the secondary school curriculum design is helping learners to be self-employed, all said 'yes' because learners received good knowledge and ability in practical skills.

Furthermore, DEOs commented on strategies used by teachers in their district councils for implementation of practical skills among learners as follows: Of the 3 DEOs, 66.7 percent of them stated that:

Strategies that teachers used were organizing Environmental clubs, Malihai clubs,

debates, subjects' clubs and planting trees. These were done as nation building tasks.

These strategies correspond to similar strategies as those found in the study done by Rafai et al. (2014) in Nigeria. Other DEOs stated that:

Learners did practical tasks frequently in science subjects where availability of

resources were assured.

One DEO commended that:

Laboratories are available in all our secondary schools and the government has abandoned alternative to practical questions in the National Form four examinations' inorder to enable learners to do real science practical.

This corresponds to Vygotsky (1998) who says that learners become active in the mental and motor activities through doing practical activities. Additionally, DEOs reported that: practical skills were not only limited to science subjects but had scaled out even to arts and music subjects.

For example, one DEOs said that:

For Arts subjects like music learners do practical of learning how to play and sing songs which can become a career to them, teachers organize field visit projects, for example visitinghistorical sites for history and geography subjects (11/9/2020). This concurs with Rafaiet al. (2014) who identified teaching strategies enhancing practical skills in Nigeria such as organizing field trips, and demonstrations. The researcher was again interested in knowing the common practical skills developed for the realization of Vision 2025

\subsection{Rating the Common Practical Skills in Implementation of Practical Skills for the Realization of Vision 2025}

The researcher was again interested in knowing which common practical skills were developed by secondary school teachers in teaching practical skill subjects among learners. Thus, the researcher asked teachers to rate the common practical skills which were developed among learners and the data are summarized in table 5.

\begin{tabular}{|c|c|c|c|c|c|c|c|c|c|c|c|c|}
\hline $\begin{array}{c}\text { Practical } \\
\text { skills }\end{array}$ & \multicolumn{2}{|c|}{ Not used } & \multicolumn{2}{c|}{$\begin{array}{c}\text { Very } \\
\text { rarely }\end{array}$} & \multicolumn{2}{c|}{ Rarely } & \multicolumn{2}{c|}{ Often } & \multicolumn{2}{c|}{ Very often } & \multicolumn{2}{c|}{$\begin{array}{c}\text { Descriptive } \\
\text { statistics }\end{array}$} \\
\hline & $\mathbf{f}$ & $\mathbf{0}$ & $\mathbf{f}$ & $\mathbf{\%}$ & $\mathbf{f}$ & $\mathbf{\%}$ & $\mathbf{f}$ & $\mathbf{\%}$ & $\mathbf{f}$ & $\mathbf{\%}$ & Mean & $\begin{array}{c}\text { Standard } \\
\text { deviation }\end{array}$ \\
\hline $\begin{array}{c}\text { Problem } \\
\text { Solving }\end{array}$ & 0 & 0 & 2 & 1.8 & 2 & 1.8 & 40 & 36.4 & 66 & 60 & 4.55 & 0.630 \\
\hline $\begin{array}{c}\text { Decision } \\
\text { Making }\end{array}$ & 0 & 0 & 0 & 0 & 4 & 3.8 & 54 & 50.9 & 48 & 45.3 & 4.42 & 0.567 \\
\hline $\begin{array}{c}\text { critical } \\
\text { Thinking }\end{array}$ & 0 & 0 & 2 & 1.9 & 4 & 3.8 & 45 & 42.5 & 55 & 51.9 & 4.44 & 0.663 \\
\hline $\begin{array}{c}\text { creative } \\
\text { Thinking }\end{array}$ & 0 & 0 & 3 & 2.8 & 6 & 5.6 & 40 & 37 & 59 & 54.6 & 4.44 & 0.727 \\
\hline Discussion & 0 & 0 & 1 & 0.9 & 3 & 2.8 & 40 & 37 & 64 & 59.3 & 4.55 & 0.602 \\
\hline Debating & 1 & 1 & 3 & 2.9 & 11 & 10.5 & 47 & 44.8 & 43 & 41 & 4.22 & 0.820 \\
\hline Presentations & 0 & 0 & 2 & 1.8 & 14 & 12.7 & 49 & 44.5 & 45 & 40.9 & 4.25 & 0.744 \\
\hline $\begin{array}{c}\text { Analysis of } \\
\text { texts }\end{array}$ & 2 & 2 & 3 & 2.9 & 14 & 13.7 & 40 & 39.2 & 43 & 42.2 & 4.17 & 0.913 \\
\hline $\begin{array}{c}\text { Co-produced } \\
\text { reports }\end{array}$ & 0 & 0 & 4 & 4 & 23 & 23 & 42 & 42 & 31 & 31 & 4.00 & 0.841 \\
\hline Experiments & 0 & 0 & 1 & 1 & 13 & 12.4 & 44 & 41.9 & 47 & 44.8 & 4.30 & 0.722 \\
\hline $\begin{array}{c}\text { Improvising } \\
\text { materials }\end{array}$ & 0 & 0 & 4 & 3.6 & 8 & 7.3 & 52 & 47.3 & 46 & 41.8 & 4.27 & 0.753 \\
\hline
\end{tabular}




\begin{tabular}{|c|c|c|c|c|c|c|c|c|c|c|c|c|}
\hline $\begin{array}{c}\text { Practical } \\
\text { Skills }\end{array}$ & \multicolumn{2}{|c|}{ Not Used } & \multicolumn{2}{c|}{$\begin{array}{c}\text { Very } \\
\text { Rarely }\end{array}$} & \multicolumn{2}{c|}{ Rarely } & \multicolumn{2}{c|}{ Often } & \multicolumn{2}{c|}{ Very Often } & \multicolumn{2}{c|}{$\begin{array}{c}\text { Descriptive } \\
\text { Statistics }\end{array}$} \\
\hline & $\mathbf{f}$ & $\mathbf{\%}$ & $\mathbf{f}$ & $\mathbf{\%}$ & $\mathbf{f}$ & $\mathbf{\%}$ & $\mathbf{f}$ & $\mathbf{\%}$ & $\mathbf{f}$ & $\mathbf{\%}$ & Mean & $\begin{array}{c}\text { Standard } \\
\text { Deviation }\end{array}$ \\
\hline Demonstration & 0 & 0 & 1 & 1 & 12 & 11.5 & 45 & 43.3 & 46 & 44.2 & 4.31 & 0.712 \\
\hline Digital literacy & 2 & 1.9 & 5 & 4.7 & 40 & 37.4 & 28 & 26.2 & 32 & 29.9 & 3.78 & 0.993 \\
\hline $\begin{array}{c}\text { Independent } \\
\text { thinking }\end{array}$ & 1 & 0.9 & 1 & 0.9 & 46 & 42.6 & 29 & 26.9 & 31 & 28.7 & 3.81 & 0.898 \\
\hline $\begin{array}{c}\text { Developing } \\
\text { projects }\end{array}$ & 0 & 0 & 3 & 3.1 & 26 & 27.1 & 37 & 38.5 & 30 & 31.2 & 3.98 & 0.846 \\
\hline Role Playing & 7 & 6.7 & 2 & 1.9 & 18 & 17.1 & 46 & 43.8 & 32 & 30.5 & 3.90 & 1.073 \\
\hline Drama & 9 & 8.7 & 5 & 4.9 & 35 & 34 & 21 & 20.4 & 33 & 32 & 3.62 & 1.230 \\
\hline Story Telling & 11 & 10.5 & 0 & 0 & 31 & 29.5 & 31 & 29.5 & 32 & 30.5 & 3.70 & 1.210 \\
\hline
\end{tabular}

Table 5: Responses of Teachers on the Common Practical Skills Developed-Generic $(N=110)$

Source: Field Data, (2020)

Referring to table 5 , the responses on the common practical skills developed by teachers included problem solving $(M=4.55, S D=0.63)$, discussion $(M=4.55, S D=0.602)$ and creative thinking $(M=4.44, S D=0.727)$ all of which had mean scores above average. The teachers said they used them very often meaning that they were used very much and enabled learners to get a lot of abilities in practical skills for the realization of Vision 2025. Similarly, many teachers said demonstration and experiments were very often developed respectively in ordinary level secondary schools. The results also showed that about half of the respondents said that debate was very often practical skill developed.

The percentages of responses and mean scores were all above average which meant that majority of these practical skills were often and very often developed. This was so because the mean scores of rating the items ranged from $\mathrm{M}=3.62$ to 4.55 and the small SD indicate majority teachers rated the same practical skills that were often and very often developed. This then implied that learners were getting many practical skills for the realization of Vision 2025. Teachers through these practical skills helped learners to capture and retain knowledge through learning by doing Dewey, (1956) and this links theory and practice. This is also in line with Rafai et al. (2014) who found that learners who acquire practical skills in learning got gainful knowledge for employment opportunities in the labour market and were also able to establish themselves on their own and become self-reliant. Also, Wagner (2018) commented that practical skills for learners are important in that practical work promotes experiential learning and not only that but also practice makes things perfect and permanent. The researcher too wanted to know the common practical skills used by learners.

\subsection{Responses of Learners on Common Practical Skills They Use in Their Respective Schools}

In connection to that, the researcher sought information from learners about the common practical skills they used at their secondary schools in order to counter check with what their teachers had said. The learners rated the common practical skills and their responses are summarized in Table 6.

\begin{tabular}{|c|c|c|c|c|c|c|c|c|c|c|c|c|}
\hline & \multicolumn{2}{|c|}{ Not Used } & \multicolumn{2}{|c|}{$\begin{array}{c}\text { Very } \\
\text { Rarely }\end{array}$} & \multicolumn{2}{|c|}{ Rarely } & \multicolumn{2}{c|}{ Often } & \multicolumn{2}{c|}{$\begin{array}{c}\text { Very } \\
\text { Often }\end{array}$} & \multicolumn{2}{c|}{$\begin{array}{c}\text { Descriptive } \\
\text { Statistics }\end{array}$} \\
\hline Practical Skills & $\mathbf{f}$ & $\mathbf{\%}$ & $\mathbf{f}$ & $\mathbf{9}$ & $\mathbf{f}$ & $\mathbf{\%}$ & $\mathbf{f}$ & $\mathbf{\%}$ & $\mathbf{f}$ & $\mathbf{\%}$ & Mean & $\begin{array}{c}\text { Standard } \\
\text { Deviation }\end{array}$ \\
\hline Problem Solving & 2 & 0.5 & 7 & 1.8 & 20 & 5.1 & 147 & 37.7 & 214 & 54.9 & 4.45 & 0.721 \\
\hline Decision Making & 11 & 2.8 & 6 & 1.5 & 49 & 12.6 & 134 & 34.5 & 188 & 48.5 & 4.24 & 0.933 \\
\hline Critical Thinking & 10 & 2.6 & 17 & 4.4 & 41 & 10.6 & 138 & 35.8 & 180 & 46.6 & 4.19 & 0.973 \\
\hline Creative Thinking & 10 & 2.6 & 22 & 5.7 & 41 & 10.6 & 131 & 33.8 & 184 & 47.4 & 4.18 & 1.005 \\
\hline Discussion & 1 & 0.3 & 3 & 0.8 & 16 & 4.1 & 101 & 25.8 & 270 & 69.1 & 4.63 & 0.627 \\
\hline Debates & 11 & 2.8 & 28 & 7.1 & 66 & 16.7 & 140 & 35.4 & 150 & 38.0 & 3.99 & 1.041 \\
\hline Presentations & 2 & 0.5 & 5 & 1.3 & 20 & 5.2 & 103 & 26.9 & 253 & 66.0 & 4.57 & 0.702 \\
\hline Analysis of texts & 16 & 4.3 & 29 & 7.8 & 61 & 16.4 & 103 & 27.7 & 163 & 43.8 & 3.99 & 1.142 \\
\hline Co-produced reports & 45 & 12.3 & 31 & 8.5 & 73 & 19.9 & 124 & 33.9 & 93 & 25.4 & 3.52 & 1.292 \\
\hline Experiments & 11 & 2.8 & 26 & 6.7 & 38 & 9.8 & 116 & 29.8 & 198 & 50.9 & 4.19 & 1.046 \\
\hline Improvising & 19 & 5.1 & 24 & 6.5 & 73 & 19.7 & 147 & 39.6 & 108 & 29.1 & 3.81 & 1.084 \\
\hline materials & & & & & & & & & & & & \\
\hline Demonstration & 20 & 5.3 & 28 & 7.4 & 78 & 20.5 & 112 & 29.5 & 142 & 37.4 & 3.86 & 1.154 \\
\hline Digital literacy & 89 & 22.7 & 72 & 18.4 & 70 & 17.9 & 91 & 23.2 & 70 & 17.9 & 2.95 & 1.429 \\
\hline Independent thinking & 79 & 20.5 & 17 & 4.4 & 80 & 20.8 & 101 & 26.2 & 108 & 28.1 & 3.37 & 1.456 \\
\hline Developing projects & 57 & 15.2 & 28 & 7.5 & 58 & 15.5 & 132 & 35.3 & 99 & 26.5 & 3.50 & 1.360 \\
\hline Role Plays & 59 & 15.9 & 42 & 11.3 & 77 & 20.7 & 109 & 29.3 & 85 & 22.8 & 3.32 & 1.363 \\
\hline Drama & 66 & 17.1 & 46 & 11.9 & 91 & 23.5 & 111 & 28.7 & 73 & 18.9 & 3.20 & 1.344 \\
\hline Story Telling & 58 & 14.9 & 17 & 4.4 & 86 & 22.1 & 115 & 29.5 & 114 & 29.2 & 3.54 & 1.348 \\
\hline
\end{tabular}

Table 6: Responses of Learners on the Common Practical Skills They Use in School $(N=396)$

Source: Field Data, (2020) 
The data from table 6 indicates that 69.1 percent $(M=4.63, S D=0.627)$ and around 66 percent $(M=4.57, S D=0.702)$ of learners said that discussion and presentations respectively were very often practical skills used. Also, problem solving, decision making, critical thinking and creative thinking were often and very often used. Since all mean scores were above average and a high SD, this means that learners received a lot of practical skills through the practical activities done. This concurs with (TIE, 2013,) and Muneja, (2015) who commented that practical skills which promote learning through doing makes learners to be active participants in the process of learning. Presentations help the learner to be confined to a fixed length of time(www.people.vcu.edu>proposal,retrieved 21/3/2021) and experiments involve the learner to think , prepare and arrange in a logical manner what is to be presented ; and experiments enable the learner to perform the experiment , analyze it and reach conclusions, this enhances critical thinking.

Few learners said that drama and role-play respectively were very often practical skills used as compared to proportions of other items. The highest mean score was found to be discussion $(M=4.63)$ while the least mean score which was below average was field trips $(M=2.95)$, meaning that learners participated a little in field trips and more in discussions.

These practical skills reported by learners enhanced learning through doing, Dewey (1956) and interacting with each other in activities such as drama, role play and field trips. In addition, these practical skills were most significant for learners to explore knowledge through interactive learning and this improved their quality of education. This is in line with Rafai et al. (2014) and TIE (2013). Also, the findings of both teachers and learners showed consistency because they interacted with each other.

DEOs too supported learners by reporting that:

Teaching and learning in ordinary secondary schools were mainly participatory and enhanced, discussion, demonstration and interactive lectures (TIE ,2013), (Rafaiet al.2014). This was made possible because 66.7 percent of DEOs stated that, Our teachers deliver these practical skills among learners since they had been receiving refreshers' training and seminars on teaching in action (TIA) from Mwenge Catholic University facilitators.

The facilitators helped to deliver strategies such as interactive lectures to teachers in order for them to teach learners the practical skills well. This is in line with Machingambi (2017) who commended that teacher needed refresher courses. This also concurs with the recommendation of (Kafyulilo et al. 2016) who recommended that there should be training of pre service teachers in new technologies such as ICT to enable them teach secondary school learners. The researcher was interested in asking learners to say YES or NO to the practical skill activities they performed.

\subsection{Acceptance of Learners for the Different Practical Skill Activities They Performed}

The researcher too wanted the learners to say YES or NO to the practical skill activities they personally performed in their respective secondary schools. The learners' responses are summarized in table 7.

\begin{tabular}{|c|c|c|c|c|}
\hline \multirow{2}{*}{ Practical Skill Activities } & \multicolumn{2}{|c|}{ Yes } & \multicolumn{2}{c|}{ No } \\
\cline { 2 - 5 } & f & $\mathbf{\%}$ & f & \% \\
\hline I participate in farming & 174 & 44.1 & 221 & 55.9 \\
\hline I am involved in live stock & 105 & 26.6 & 290 & 73.4 \\
\hline I make bricks & 56 & 14.2 & 339 & 85.8 \\
\hline I help in house building & 62 & 15.7 & 333 & 84.3 \\
\hline I do some needle work & 106 & 26.8 & 289 & 73.2 \\
\hline I do cookery & 151 & 38.2 & 244 & 61.8 \\
\hline I do laundry & 137 & 34.7 & 258 & 65.3 \\
\hline I do carpentry & 55 & 13.9 & 340 & 86.1 \\
\hline I participate in field trips & 182 & 46.1 & 213 & 53.9 \\
\hline I Manage our school shop & 111 & 28.2 & 283 & 71.8 \\
\hline I do vegetable gardening & 137 & 34.7 & 258 & 65.3 \\
\hline I use computer for searching information & 143 & 36.3 & 251 & 63.7 \\
\hline $\begin{array}{c}\text { I have ability to present topic in front of } \\
\text { class }\end{array}$ & 312 & 79.0 & 83 & 21.0 \\
\hline I do some crafts & 138 & 34.9 & 257 & 65.1 \\
\hline $\begin{array}{c}\text { I have ability of creative thinking and } \\
\text { reasoning }\end{array}$ & 326 & 82.5 & 69 & 17.5 \\
\hline I participate in sports and games & 346 & 87.6 & 49 & 12.4 \\
\hline
\end{tabular}

Table 7: Responses of Learners on Implemented Practical Skill Activities

Which They Do at School $(N=396)$

Source: Field Data, (2020)

Table 7: shows the practical skill activities which learners were taught in the focused subjects (table 1). Table 7 also shows that at least forty percent (44.1-87.6\%) of learners said 'yes' that they practice farming, this is contrary to Lupeja (2017) who commented that secondary graduates preferred non-farm activities; field trips, present a topic in front of class, creative thinking, and participate in sports and games. These findings imply that learners were also involved in manual skills as reported by their teachers. These skills accelerated quality practical education for the realization of Vision 2025 concurring with TIE (2013) and Dewey (1956) who asserts learning by doing. The findings of learners on the ability 
of practicing their skills were consistent with those of their teachers who said that learners had been acquiring practical skills in manual activities. Skills of computer, crafts, cookery and farming are technical skills which have an impact on productivity and development Odo et al. (2017) and for the realization of Vision 2025. Also, technical education has been identified as one of the most effective human resource developments that needs to be embraced for rapid industrialization and sustainable technological development of any nation (Odo et al, 2017). Therefore, these findings implied that the secondary school curriculum is preparing learners well as human resources in practical skills for the realization of Vision 2025 and this could solve the problem of unemployment in Kilimanjaro, Tanzania and globally.

\subsection{Preparation of Learners and Interlink of Practical Skills towards Employment}

The researcher too was interested to find out how well learners were prepared to acquire practical skills for employment opportunities. Teachers rated how well ordinary level secondary school learners were prepared to acquire practical skills for employment opportunities. The results showed that ninety six percent of teachers (30\%, 42\% and 24\%) rated with average, very good and excellent that learners were prepared well respectively (Fig 1). The findings indicated that teachers rated with agree and strongly agree respectively that there was an inter-link of practical skills and employment opportunities. This was supported by majority heads of schools $(90.2 \%$ out of $n=11)$ who agreed that the secondary school curriculum design is helping learners to be self-employed which is in line with ETP, (1995) which asserts that secondary education prepares graduates for both the world of work and for further education.

These findings too provide evidence that there is a significant relationship between practical skills and employment opportunities because the Likert scale statements had mean scores of (M=3.87), and that acquisition of practical skills had a direct interlink with employment opportunities (Fig 1). These findings too were in line with TIE (2013) who said that learners who had practical oriented skills had higher chance of being employed than those without. Hence secondary school learners have better opportunities of employment.

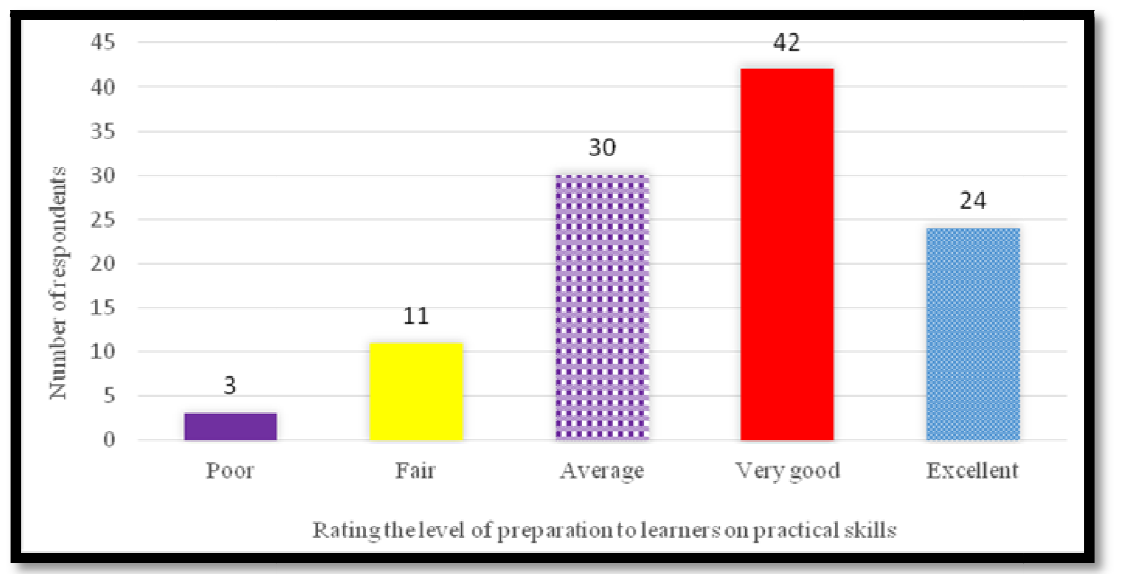

Figure 1: Preparation of Learners to Acquire Practical Skills for Employment $(N=110)$ Source: Field Data, (2020)

\subsection{Hypotheses Testing}

The researcher was interested in testing the relationship between rate mean scores of strategies used by secondary school teachers and implementation of practical skills for the realization of Vision 2025 at ordinary level secondary schools. In arriving at the conclusion of the study, the researcher used linear regression in testing the linear relationship between independent and dependent variables.

\subsection{Hypothesis 1}

- $\quad$ Null hypothesis (Ho): There is no significant relationship between rate mean scores of strategies used by secondary school teachers and implementation of practical skills for the realization of Vision 2025 among secondary school learners.

The researcher tested the null hypothesis (Ho) by using linear regression and the model summary is presented in table 8.

\begin{tabular}{|c|c|c|c|c|}
\hline Model & R & R Square & Adjusted R Square & $\begin{array}{c}\text { Std. Error of the } \\
\text { Estimate }\end{array}$ \\
\hline 1 & $.474^{\mathrm{a}}$ & .224 & .217 & .86665 \\
\hline \multicolumn{4}{c|}{ a. Predictors: (Constant), strategies Vision } \\
\hline \multicolumn{3}{c|}{ Table 8: Model Summary } \\
Source: Field Data 2020
\end{tabular}

The findings show that the variables had $(\mathrm{r}=0.474)$ significant degree of relationship. The results evidenced that $21.7 \%$ of dependent variable, variability was determined by strategies of implementing Vision 2025 (adjusted R square $=0.217$ ).

In ANOVA table p-value, degree of freedom and f-value were obtained. The findings are summarized in table 9. 


\begin{tabular}{|c|c|c|c|c|c|}
\hline & Sum of Squares & Df & Mean Square & f & P-value \\
\hline Regression & 23.456 & 1 & 23.456 & 31.230 & .000 \\
\hline Residual & 81.117 & 108 & .751 & & \\
\hline Total & 104.573 & 109 & & & \\
\hline
\end{tabular}

Table 9: ANOVA

Source: Field, (2020)

The results showed that there was significant variation of variances due to the regressor and residuals. This implied that variation due to regressor was statistically significant higher as compared to residuals ( $\mathrm{F}=31.230$, $\mathrm{p}$ value $=0.000<5 \%$ ). This implies that the increase of strategies on the implementation of practical skills for the realization of Vision 2025 results to higher variability on the practical skills of learners acquired.

Linear regression model was formulated showing the extent to which strategies of teachers towards implementation of practical skills on the realization of Vision 2025 influence ability of practical skills of learners acquired. The results are summarized in table 10

\begin{tabular}{|c|c|c|c|c|c|c|}
\hline \multicolumn{2}{|r|}{ Model } & \multicolumn{2}{|c|}{ Unstandardized Coefficients } & \multirow[t]{2}{*}{$\mathbf{T}$} & \multirow[t]{2}{*}{ P-value } & \multirow{2}{*}{$\begin{array}{l}95 \% \text { Confidence } \\
\text { Interval for B }\end{array}$} \\
\hline & & B & Std. Error & & & \\
\hline \multirow[t]{2}{*}{1} & (Constant) & -.333 & .711 & -.469 & .640 & $(-1.743,1.076)$ \\
\hline & $\begin{array}{c}\text { Strategies for Vision } \\
2025\end{array}$ & .945 & .169 & 5.588 & .000 & $(0.610,1.280)$ \\
\hline \multicolumn{6}{|c|}{ a. Dependent Variable: Implementing practical skills for Vision 2025} & \\
\hline
\end{tabular}

Table: 10 Coefficients

Source: Field, (2020)

The results show that, on average there is 0.945 significant increase of practical skills ability as strategies of implementation of practical skills for the realization of Vision 2025 become higher $(t=5.588, p$-value $=0.00<5 \%)$. In addition, the findings show that there is $95 \%$ confidence that the average effect 0.945 of strategies used towards implementing practical skills for the realization of Vision 2025 among learners lie between 0.610 and 1.280 in the population.

Linear Model Equation:

Let:

$Y=$ practical skills

$X$ =strategies used towards implementing practical skills for the realization of Vision 2025

$\beta_{1}=$ effect of strategies used towards implementing practical skills for the realization of Vision 2025

$\beta_{0}=$ constant terms

$Y=\beta_{0}+\beta_{1} X$

$Y=-0.333+0.945 X$

The researcher tested the null hypothesis (Ho) by using linear regression. There was not enough evidence supporting the null hypothesis and so it was rejected and concluded that there was a significant relationship between strategies used by secondary school teachers and implementation of practical skills for the realization of Vision 2025 among secondary school learners.

\section{Findings and Conclusion of the Study}

Findings showed that commonly used strategies by secondary school teachers included assigning learners' practical activities such as farming, demonstrating practical activities and developing projects for learners; observing and assessing learners when they perform tasks; integrating ICT with teaching and learning and assessing the overall quality of the completed tasks. These strategies help learners acquire knowledge and practical skills' ability for employment opportunities. The commonly acquired practical skills (generic) included problem solving, decision making, critical thinking, creative thinking, discussions and presentations. Learners were well prepared as human resources for the realization of Vision 2025. Learners said YES personally that they were practicing these practical skill activities (Table 7 and Appendix 1). Findings too showed that there was an interlink of practical skills with employment opportunities (Fig.1).

\subsection{Conclusion}

The null hypothesis was rejected and it was concluded that there was a significant relationship between strategies used by secondary school teachers and implementation of practical skills for the realization of Vision 2025 among secondary school learners. That is as strategies increased, implementation of practical skills among learners also increased. Teachers worked very hard on developing practical skills among learners, learners too acquired practical skills for employment opportunities. Thus, secondary school curriculum is preparing learners as human resources. This could lead to the realization of Vision 2025 through secondary education, but we are not sure whether these learners after 
completing Form four, will be able to practice the practical skills learned in their daily lives and be self reliant. Also, not all secondary schools have these practical skill subjects such as agriculture, home economics and computer.

\subsection{Recommendation of the Study Based on the Conclusions}

Basing on the conclusions of the study the following recommendations were made:

- The practical skill subjects of focus in this study such as agriculture, building construction and home economics could be made compulsory for all secondary school learners to benefit from them and NECTA to examine them.

- If this is not possible then all schools should consider introducing one practical skill subject such as agriculture

- $\quad$ Parents and the community to cooperate with teachers in making learners capable of demonstrating practical skill activities at home and at school.

- These practical skills could be intensified to A level, Tertiary and University level and the examination structure should reflect practical skill subjects.

\subsection{Recommendation for Future Studies}

For future research, a study may investigate significant factors which influence the effectiveness of practical skill activities among learners in Kilimanjaro Region, Tanzania.

\section{References}

i. Ahmed, S.A.S. (2014). Handout on Fundamental \& Organization Curriculum

ii. Amaechi, E., and Joseph, 0. (2016). Strategies of Effective Teaching and Learning Practical skills in Technical and Vocational and Training Program es in Nigeria. Journal of Vocational and Technical Education

iii. Chib, A., Wardoyo, R. J. (2018), Differential OER Impact of Formal and Informal ICTs: Employability of Female Migrants Workers. International Review of Research in Open and Distributed Learning 2018.

iv. Coch, L \& French, J.R.P, (1948). Theory of Overcoming Resistance to Change (ORC). Journals.sagepub.com>doi (Retrieved 20/5/2021).

v. Dewey, T. $(1915,1956)$. The School and Society. Chicago. University of Chicago Press pp12-15,1829/Amazon/World Cat. (Retrieved 10/4/2019).

vi. Hamamba, A., and Rao, C. (2017). Preparation and Professional Development of teachers Education in Tanzania: Current Practices and Prospects. Journal of Education and Practice 2017, Vol. 8 no. 8.

vii. Hernandez, C., Florez, F. B., Tacora, M.A., Leon, D. (2018). Problem based learning and development of professional competences in the field of biomedical engineering-Tojet -The Turkish on line Journal of Educational Technology, Vol. 17, Issue 3.

viii. Kafyulilo, A.C.; Rugambuka, B.L.; Moses, I. (2012). The implementation of Competence Based Teaching Approaches in Tanzania.Makerere Journal of Higher Education ,4 (2), 311-326

ix. Kinyaduka, B.D. (2014). Tanzania Secondary Schools Curriculum and the World of Work: Dodoma Municipality, Student and Teachers Percepts. Journal of Educational Policy and entrepreneurial Research (JEPER), Vol.1, No.3, Nov.2014.

x. Lupeja, T.L. (2017). Secondary Education Attainment and its Role in Poverty Reduction: Views of graduates Working in Informal Sector in Rural Tanzania. Journal of Education and Practice. Vol.8, No. 11(2017).

xi. Mfaume, H. (2019). Awareness and use of mobile phone as a Potential Pedagogical tool among

xii. Secondary School Teachers in Tanzania. International Journal of Education and development using Information and Communication, Technology 2019, Vol.15, issue 2, pp154-170

xiii. Mtebe, J.S.; Joel, S.; Raphael, C. (2018). Eliciting in service Teachers' Technological Pedagogical Content Knowledge for $21^{\text {st }}$ Century Skills in Tanzania. Journal of Learning for Development, 2018.

xiv. Muneja, M.S. (2015). Secondary School Teachers' Implementation of Competence-Based Curriculum in Arusha Region, Tanzania. (Masters, Dissertation)

xv. Nyerere, J.K. (1967). Education for Self Reliance. In J.K. Nyerere, Freedom and Socialism: Dar-es-Salaam, Tanzania. Oxford Press.

xvi. Odo, J.U.; Okafor, W.C.; Odo A.L.; Ejikeugwu, L.N.; Ugwuoke, C.N.;(2017). Technical Education. The key to sustainable Technological Development. Universal Journal of Education al Research 2017,5(11):1878-1884. 2017. Nigeria.

xvii. Rafai, A.; Kabin. Y; Mustafa, A.H.; Saudi, S.M. (2014). Assessment of teaching methods that influence the acquisition of Practical Life Skills. Journal of Asian Social Sciences Vol. 10. No.21, Published by Canadian Center of Sciences on Education.

xviii. Tyler, R. W. (1949). Basic Principles of Curriculum and Instruction. Chicago. The University of Chicago Press.

xix. Vygotsky, L. S, (1998). Child Psychology. The collected works of L.S. Vygotsky Vwol.5. Trans. Marie, J. Hall. New York Plenum.

xx. Wagner, K. (2018). Why students Need Practical Skills and How to teach them. 